\title{
The Power and Discursive Abuse of the Media: Hate and Discrimination as Social Consequences Presentation and Interview with the Socio-Cognitive Thinker Dr. Teun A. Van Dijk
}

\author{
Mohamed el Mouden* \\ Research Scholar, Department of Journalism, University of Seville, Spain \\ *Corresponding author: mohamedelmouden@gmail.com
}

\begin{abstract}
In this work, the Dutch critical thinker and the sociocognitive researcher on discourse and power issues, Teun A. Van Dijk, gives us a critical analysis of power and its discursive strategies for domination. It exposes us some forms of abuse of speech on the part of power (such as the media) that end up provoking hate discrimination and rejection of the other.
\end{abstract}

Keywords: Abuse of discursive power, Discourse, Discrimination, Discursive strategies, Domination, Hate, Power, Socio-cognitive.

\section{Introduction}

International events that have occurred both now and in the immediate past have contributed decisively to establishing a socio-political context that feeds the production of discourses of hate and discrimination. Since Trump's arrival at the White House in 2017 and the rise of the extreme right in European countries, in some of which this political force even came to power, such as in Italy and in Brazil, the Brexit process was also based on anti-immigration discourses, not to mention the complicity of the dominant media, which serve as a bridge for ideas that encourage racism and domination against minorities, immigrants and refugees who came to Europe in search of asylum. Hate has become a rising value in the discourses of extreme right-wing political forces (Lacomba, Joan. (2020). But the most striking point is that even the forces that consider themselves centre-right democrats have fallen into the discursive trend that has marked the extreme right. They have entered into a struggle to show who is the hardest on this community of immigrants North Africans, Africans and minorities in order to find their reward at the ballot box. The concerns of the pro-human rights and pro-immigration associative fabric, as well as of those committed to communication and diversity, has have increased, warning of the consequences of hate speech on democratic values and coexistence, which are major the achievements of modern
European societies.

Moreover, one day before the US President Trump declared his decision to prevent the entry of citizens from seven countries, most of them Muslims, into the United States, journalists from all over the world met in Brussels with European Union officials in order discuss the hate speech against immigration and refugees (Claudi, Pérez 2017). This kind of speech endangers the coexistence and diversity that form the basis of today's democratic society and indirectly it reveals the responsibility of the media in promoting such hate speech.

In these circumstances, the analytical and socio-cognitive experience of the Dutch thinker, linguist, and philosopher Teun. A. van Dijk, as well as his long-accumulated experience involvement in analyzing the discourse of the media and the dominant powers on immigration and refugees gives us access to an area of critical thinking, within which he developed a deep socio-cognitive reflection on the abuses of power in discourse. Those abuses end up producing discrimination, hate and racism. Teun considers that power legitimizes its policies through discourse, and he became involved in the task of dissolving power structures and their ways of producing a discourse of domination over subjects, groups, classes, and identities.

Van Dijk strongly criticizes the media as representing the great source of discourse construction and public opinion formation where abuses of power are exercised and cause discrimination, hatred, and manipulation (Van Dijk, T.A. 1991). He never discusses this abuse in their thematic agendas or tries to develop a critical position of the discursive abuses that the media commit. One aspect of this abuse of discursive power is the self-centeredness that manifests itself by presenting the self (the subject) in a positive way and others in a negative way. For van Dijk it is produces a discursive strategy to exercise domination (Van Dijk, Tuen A. 2008).

And to get closer to the different forms of abuse of power 
that are exercised through the dominant discourses produced by the media on immigrant communities and that cause discrimination and hate, I had the honors and opportunity to interview Dr. Tuen Van Dijk, a Dutch thinker, linguist, and specialist in the socio-cognitive study of discourse. He is one of the world's great critical thinkers who dedicated his sociocognitive theory to revealing the discursive strategies of discourse and power adopted to exercise dominance and to delimit social consequences such as discrimination, racism and hate.

- How did you become interested in the issue of racism in your sociocognitive project?

T.V.D: Around 1980 I wanted to give a more social dimension to my work on discourse, after a more linguistic, formal, and cognitive period. I wanted to deal with an important social issue, which was not much worked on in the Netherlands in the 1970s, and I chose the topic of racism after a long visit to Mexico in 1980. I was also increasingly interested in the representation of the Third World and Third World people (immigrants, etc.) in the discourses of the North. A topic that still interests me a lot today.

By the way, I would not call my project "cognitive", but rather "socio- cognitive" because I am interested in both the social aspects (such as discrimination, institutions, etc.) and the cognitive aspects of racism (prejudices, ideologies).

- And why has media discourse (the press) been one of the fields that has covered your questioning of racism?

T.V.D: I was interested in the press not only because of the issue of racism, but more generally because of the importance of their discourses for the formation of knowledge and ideologies in society. Moreover, news is a very interesting genre, which in the 1980 s was not very well studied. For the investigation of the discourse on racism, news was of particular interest to me because it is the most important source of information on immigration, and the basis for the formation of prejudices and ideologies.

- How would you define racism in your sociocognitive discourse?

T.V.D: Racism is a social system of abuse of power, of historical domination of white (European) people over nonEuropean people. It consists of a system of everyday racism of social practices of discrimination (exclusion, etc.), and of a socio- cognitive system of prejudices and racist ideologies, generally reproduced by racist discourse.

- What are the conceptual structures that motivate and provoke the production of racism?
T.V.D: A system of domination as complex as racism does not have a single cause, but multiple causes and conditions, social, cultural, economic, etc. As a system of domination, what is fundamental is that the dominant group wants to maintain its domination in all areas of society: control over space, economy, culture, etc.

In the case of the media discourse produced by the Spanish press, for example, about Arabs/Moroccans, what are the main images of discriminatory tendencies that are used and handled?

T.V.D: Arab racism in Europe is very old and has its roots in the classical, Greek and Latin ages, and then from the occupation of Spain in the seventh century, on the one hand, and the power of the Ottoman Empire on the other. It is a combination of political and economic racism based on images of an enemy people, on the one hand, and as well as sociocultural because of the negative representation of Islam by Christians. In other words, the representation is generally a mixture of anti-Islam and anti-Arabism. Edward Said showed in his book (Said, E. (2003), the history of the dominant racist images of Arabs in European ideologies, images that today are merged with an amalgam of ideologies on terrorism and Islamism: The Arab as (very) different, threatening, unreliable, extremist, on the one hand, and on the other, historically, also mixed with images of luxury and lust, of the harem on the other hand. It is a complex ideology with many historical variable dimensions, but with some permanent features. Today, and particularly after 11 September it occurred, and the massive immigration of Muslims to Europe; the dominant image of the ideology is that of violent extremism and religious fundamentalism. But there is much more, which cannot be explained in one answer.

- Is the same thing happening with the Dutch press? You have also worked on this press and there are a lot of immigrants there.

T.V.D: The Dutch press is not very different from the Spanish press and in that sense one can talk about a European press, with different nuances. The right-wing journalism (especially popular, like the tabloids in England, Germany, Denmark, etc.) is more anti-Arab and anti-Islam than the left-wing press.

- To what extent have the heritage of colonialism and Orientalism and also the new international contexts, such as the fight against terrorism, fed into the racist tendency of the discourses dealing with this other in the western press?

T.V.D: As I said, contemporary anti-Arab racism is not new, but it has a long history in the Orientalism of European elites.

- You have devoted much critical reflection to discourse and racism. What are the cases that you consider exemplary in 
exposing these modes of discourse that produce and manifest this imbalance between the self and the other and of course create as consequences racist attitudes?

T.V.D: With my students we have studied a little the case of anti-Muslim cartoons, and the general conclusion is twofold: on the one hand, we have the stereotypical description of Muslims as violent, intolerant and culturally backward and on the other hand there is the emphasis on our positive values of freedom of the press, etc. This polarization between us and them, between West and East, between Islam and Christianity, etc. is quite common in ideologies, and the discursive strategy is also very frequent: emphasizing the bad points about them and the good concepts about us. But also: to de-emphasize the bad things about us (there is no talk about racism in Europe, nor about the holocaust, colonialism, etc.) or the good things about them (there is no speech) about the moderate, modern, and in general diversity forces, etc.), about Islam not about the bad things of Christian fundamentalism, and its influence on Bush, and therefore on the whole world....

- The existence of racism in a social media discourse puts the notion of diversity and pluralism in that society at a point of evaluation. Do you think that the press and media handle a revisable concept of diversity and pluralism?

T.V.D: Obviously. It is fundamentally inconsistent with the values of democracy, equality, diversity, etc. And that conclusion is not daily read in the press, although of course there are anti-racist people who tell that every day, but they have less access to the media. For example, research results on racism in the press are not published in it.

- How do you evaluate from the results of your long cognitive reflection in media discourses the question of identity construction? Do they have a fixed mechanism?

T.V.D: This is a very general and difficult question. The construction of identities is a complex process of social and cultural conditions. In our work, the approach to identity is formulated from a discursive and socio-cognitive perspective: the identity of a group or community is a mental representation shared by the members of the group (as well as knowledge and ideology), and is reproduced by the social practices of the members of the group and above all by the discourses.

- Terrorist attacks committed by fanatical groups form the context where the greatest number of conceptual consequences on the other usually occur. To what extent have these events decisively marked the production of a dominant and classifying discourse on linked identities?

T.V.D: Of course, the New York and Madrid attacks for example (and others elsewhere) have a profound influence on western representations of Arabs and Muslims, and one can see the consequences on anti-terrorist and anti-immigration policy, such as the founding and success of a racist party (by Fortuyn) in the Netherlands. But I repeat that it is nothing new and not fundamentally different from the reactions in Europe when the Turks were at the gates of Vienna some centuries ago The worst thing is that the attacks are always the best excuse for racist ideologies, because they seem to confirm the negative judgements and prejudices, and therefore the generalization about all Arabs and Muslims. We do not simply talk about terrorists in general (Muslim fundamentalists, Christians, Hindus, nationalists, ETA, Ireland, etc.) as violent men, but preferably as Arab and Muslim terrorists: that is different from our terrorists, as in the United States, Europe, etc. That is why anti-terrorism is in practice a racist ideology.

- The media can say that there are confusing limits between criticism of the racist tendency of their speech and freedom of expression. How do you see this equation? Is there a contradiction between the critical analysis of the issue of racism in press speech and the principle of freedom of expression?

T.V.D: The argument of freedom press is the core of the professional ideology of journalists, just as "freedom" is the core of neo-liberal ideology, etc. This freedom is basically a form of power being able to say or do what one wants, without outside control (of the State, etc.). Any criticism of the media, especially in the area of racism, is responded to with an emphasis on freedom of the press, because criticism is interpreted as a desire to control the media, as an attempt to limit their freedom to write even racist reports. The problem is that journalists forget that freedom of the press, historically, was the freedom against other powers, such as the state, and not the freedom to oppress minorities with racist news. The absolute freedom of a group or organization that has the power is a dictatorship. Every powerful group or organization in society needs to be controlled with laws, rules, etc. against the abuse of its power. This has nothing to do with a limitation on the freedom of the press, but a limitation on the abuse of power by the press.

- Are the media in general interested in putting the results of their critical and socio-cognitive reflection on the subject of racism into the discourses they produce in their considerations?

T.V.D: The problem is that journalists are the only profession about which negative news and opinions are not published in the press. And therefore, they are not used to fundamental criticism, and their ideology of press freedom is employed to defend themselves against that reproval. In my experience, and after having analyzed thousands of articles in the press, antiracist criticism of the press is not published in the in it: that is 
the strongest taboo in the press. Therefore, when the press claims freedom of the press, it does not accept the freedom of science and minority groups to criticize the press. Those who criticize the press are marginalized, excluded, ridiculed, attacked, problematized. I do not know of any newspaper in the world that is explicitly anti-racist and publishes regularly on racism in the press.

- Can we see you in the future working on the discourses of the Arab press as you have done with the Latin American press, for example?

T.V.D: If I knew Arabic, of course it would be a possibility, because I have no illusion that the Arab press (despite its enormous diversity between Syria and Morocco) is fundamentally different. But it's a job of critical analysis that my Arab colleagues have to do, and I hope that my work will inspire those jobs. We know about forms of anti-Semitism in the Arab press (understandable given the situation of Israeli oppression of the Palestinian people, but therefore not legitimate, because it is not something that can be attributed to all Jews, nor can terrorist attacks or extremist Islamist men be attributed to all Muslims). There is certainly a long tradition of anti-black racism among Arabs, as there was in Europe as well, and this is probably true for anti-Asian racism as well, etc. However, prejudice is one aspect the power to dominate others is another, and racism, as I define it, involves that form of abuse of power and domination. Anti-black prejudices in the Arab world become racist when Arabs can dominate and persecute black people, as is the case in some countries, at this moment more tragically in Darfur.

- Your socio-cognitive process has been diverse, rich and long (34 books, and more), it has dealt with questions of discourse and ideology, of literary and non-literary texts, and from various conceptions of linguistic knowledge, semantics and also pragmatics etc., where are you now directing your concerns and cognitive research?
T.V.D: As I said, my works are not only "cognitive", but rather multidisciplinary, combining discourse analysis with critical analysis of society and social cognition. After my work on racism, I have mainly worked on ideology, and in recent years on context (on which I have just finished two books). My new project is again multidisciplinary and deals with the relationship between discourse and knowledge.

- How do you see the power of knowledge in the eyes of other powers: media and politicians.... when it comes to managing future European societies that are perhaps more multiethnic because of immigration?

T.V.D: I am not very optimistic about the power of knowledge, or of critical science over the other powers, because our values, objectives, etc. are inconsistent with those of the other powers, politicians, the media, companies, etc. The little power (influence, force) we have is cultural (we can publish books, more or less freely, even though our books will never be bestsellers) on the one hand, and on the other hand educational: we can educate students and thus perhaps inculcate some antiracist ideas in a future generation of journalists, politicians, etc. Politically, what we can do is to do the research that the opposition forces need, of the descent.

\section{Conclusion}

This paper presented an overview on the, power and discursive abuse of the media, hate and discrimination as social consequences presentation and interview with the sociocognitive thinker Dr. Teun A. Van Dijk.

\section{References}

[1] C. Pérez, "Bruselas censura el veto migratorio de Donald Trump," 2017. https://elpais.com/internacional/2017/01/30/actualidad/1485780050_694 566.html

[2] L. Joan, "Explotar políticamente la inmigración: Recuperet," 2020, https://elpais.com/elpais/2020/03/12/migrados/1584005440_724908.htm 1

[3] S. Edward, “Orientalism,” New York Pantheon, 1978.

[4] A. Van Dijk, Tuen, "Discourse and Power. Barcelona: Gedisa," 2008.

[5] T. A. Van Dijk, "Racism and the Press. London: Routledge," 1991. 